\title{
High-moisture sorghum grain silage with low- and high-tannin contents for weanling piglets
}

\author{
Ana Beatriz Rocha de Castro Lopes ${ }^{1}$ Marcos Lívio Panhoza Tse ${ }^{2}$ Anália Maria Ribeiro da Silva ${ }^{1}$ \\ Messias Alves da Trindade Neto $^{3}$ Carolina Silva Pereira ${ }^{2}$ \\ Mayra Anton Dib Saleh ${ }^{2 *}$ Dirlei Antonio Berto ${ }^{2}$
}

${ }^{1}$ Programa de Pós-graduação em Zootecnia, Universidade Estadual Paulista (UNESP), Botucatu, SP, Brasil.

${ }^{2}$ Departamento de Produção Animal, Universidade Estadual Paulista (UNESP), 18618-000, Botucatu, SP, Brasil. E-mail: dib_saleh@yahoo.com.br. ${ }^{*}$ Corresponding author.

${ }^{3}$ Departamento de Nutrição e Produção Animal, Universidade de São Paulo (USP), Pirassununga, SP, Brasil.

ABSTRACT: Sorghum is the second cereal used in pigs' diets in Brazil, which has a lower cost than corn, thus this experiment aimed to study the effects of high-moisture sorghum silage grain with high-and low-tannin contents on silage quality and piglets' performance. A total of seventytwo weaned piglets were allocated into randomized blocks with six replicates and four treatments, based on diets with dry corn grain (DCG); dry sorghum grain with low-tannin (LTSG), high-moisture sorghum grain silage with low-(LTSS) and high-tannin (HTSS). The ensiling process decreased total and condensed tannin contents to 31\% and 98\% for LTSS and, to $80 \%$ and 93\% for HTSS, respectively. No treatment effects observed on average daily feed intake and average daily weight gain. The feed:gain ratio of piglets fed LTSS was greater than piglets fed LTSG. At total period, piglets fed HTSS showed a similar feed:gain ratio than piglets fed DCG or LTSG, although it was worse than animals fed LTSS. The LTSS and HTSS can replace corn or sorghum dry grains in diets of weanling pigs with no adverse effects on growth performance. Key words: ensiling process, performance, pigs, sorghum grain.

Silagem de grãos úmidos de sorgo com alto e baixo tanino para leitões recém-desmamados

RESUMO: O sorgo é o segundo cereal mais utilizado nas dietas de suínos no Brasil e possui menor custo em relação ao milho. Neste contexto, este experimento objetivou estudar os efeitos da silagem de grãos úmidos de sorgo baixo e alto tanino na qualidade da silagem e desempenho de leitões. Utilizaram-se 72 leitões na fase de creche alocados em blocos ao acaso, com quatro tratamentos e seis repetições. Os tratamentos foram dietas à base de grãos de milho seco (M), grãos de sorgo seco baixo tanino (SSBT), silagem de grãos úmidos de sorgo com baixo (SBT) ou alto tanino (SAT). A ensilagem reduziu os teores de taninos totais e condensados em 31\% e 98\% para a SBT e, em $80 \%$ e 93\% para a SAT, respectivamente. Não houve efeito dos tratamentos no consumo diário de ração e ganho diário de peso. A conversão alimentar dos leitões que receberam SBT foi melhor que a daqueles alimentados com dietas com SSBT para os periodos estudados. No período total, os leitões que receberam dietas com SAT apresentaram conversão alimentar semelhante àqueles alimentados com dietas com M ou SSBT, porém pior que aqueles alimentados com dietas com SBT. As SBT e SAT podem substituir o milho seco e o sorgo seco baixo tanino das rações sem prejuízo ao desempenho de leitões na fase de creche.

Palavras-chave: desempenho, ensilagem, grãos de sorgo, suínos.

\section{INTRODUCTION}

Sorghum has composition and nutritional value variable depending on the presence and concentration of tannins, which are phenolic compounds of high molecular weight that compromise palatability; reduced digestibility, particularly of protein and starch, interfering with minerals and vitamins absorption and retention (SCHOFIELD et al., 2001).

Indeed, feedstuffs that commonly are used in preparing diets for animals can be subjected to several processing forms, in order to inactivate or destroy any antinutritional factors and thus, improve digestibility. The ensiling process of sorghum grain (Sorghum bicolor (L.) Moench) is an economically feasible practice to reduce considerably tannins and other antinutritional factors. Thus, dry sorghum grain with low-tannin is a great option to pig feeding, since it has similar nutritional composition and provides similar performance as corn (PATRÍCIO et al., 2006). Besides its agronomic advantages, such as earlyharvest and release of area for other crops, the use of high-moisture silage has improved performance and it has reduced diarrhea prevalence in piglets at nursery phase (LOPES et al., 2001a) and on performance of growing and finishing pigs compared to animals fed dry corn (LOPES et al., 2001b).

Whereas in technified swine production, piglets are early-weaned at a moment that they have low stomach's ability to produce $\mathrm{HCl}$ and 
enzymatic secretion for starch digestion, contributing to its digestive immaturity (CHAMONE, 2010), the acidification of diets favored by ensiling, contributed to the improvement of sows and piglets'performance, since organic acids are utilized in diets preservation in order to stabilize $\mathrm{pH}$ and reduce buffering capacity (LEHNEN et al., 2011) and also, presents antimicrobial and immunomodulating action (TSILOYIANNIS et al., 2001), leading to a better digestibility and nutrient absorption by increasing gastric-retention time of digesta (MROZ, 2005).

Therefore, as sorghum is the second cereal used in pigs' diets in Brazil, which has a lower cost than corn, this experiment aimed to study the effects of high-moisture sorghum grain silage with high- and low-tannin contents on silage quality and piglets'performance.

\section{MATERIALS AND METHODS}

\section{Production of silages}

The sorghum grain with low- or hightannin contents were harvested at $29.33 \%$ and $29.50 \%$ of moisture levels, respectively, then grounded and ensiled within 100-L polyvinyl chloride cylindrical silos. The temperature inside silos was monitored and registered throughout 30 days with T-type copper $(+) /$ constantan (-) thermocouple, isolated in PVC, wire diameter of $0.5 \mathrm{~mm}$ coupled to data loggers that recorded readings at intervals of $10-\mathrm{sec}$, and averages every 2-hour. The system also registered the ambient temperature where the silos were stored. For production of high-moisture sorghum grain silage with low-tannin and dry sorghum grain with low-tannin, the same variety of sorghum was utilized harvested at different moisture levels.

\section{Chemical analyses of silages}

Chemical compositions of dry corn (DCG), dry sorghum with low-tannin (LTSG) and high-tannin (HTSG) and, high-moisture sorghum grain silages with low- (LTSS) and high-tannin (HTSS) are shown in table 1. At the end of ensiling process, silages were sub-sampled for $\mathrm{pH}$ analysis (CHERNEY \& CHERNEY, 2003), moisture (AOAC, 1984) and particle size quantifications (ZANOTTO \& BELLAVER, 1996).

Samples for LTSS and HTSS organic acids determinations were centrifuged at $12,000 \mathrm{rpm}$ for 8 -min. Then, it was filtered through a polyvinylidene fluoride membrane (PVDF) of $0.22 \mu \mathrm{m}$ pore size and $13 \mathrm{~mm}$ diameter (Millipore ${ }^{\circledR}$, Cork, Ireland) for retaining solid content, according to MUCK \&
DICHERSON (1988). The supernatant was injected by an automatic sampler into a chromatograph (Varian, model ProStar 410, Santa Clarita, CA) coupled to a refractive index detector with column Bio-Rad Aminex HPX-87H (Bio-Rad Laboratories, Hercules, CA, USA) at $65^{\circ} \mathrm{C}$ and flow rate of $0.6 \mathrm{~mL} /$ min for a total time of 35-min.

Samples of dry sorghum grain and highmoisture sorghum grain silages were analyzed for total and condensed tannins at Center of Nuclear Energy in Agriculture, Universidade de São Paulo, Piracicaba, Brazil. An amount of $200 \mathrm{mg}$ of ground samples $(0.25 \mathrm{~mm})$ were transferred into beckers, adding $10-\mathrm{mL}$ of $70 \%$ acetone solution, then ultrasound-extracted for 20 -min in water with ice cubes and centrifuged at $4^{\circ} \mathrm{C}$ for 10-min at 3,000x $\mathrm{g}$. The supernatant (extract) was collected and stored on ice.

For total tannin analyses, $100 \mathrm{mg}$ of polyvinylpolypyrrolidone (PVPP) was weighed in a test tube, adding 1-mL of distilled water and $1-\mathrm{mL}$ of diluted extract. After mixing, tubes were kept in cold storage for 15-min and mixed again. Then, tubes were centrifuged at 3,000x $g$ for 10 min at $4^{\circ} \mathrm{C}$ and the supernatant collected. From this point on and, with remaining extract, the procedures for determination of total phenols were performed and, from the difference between total phenols and phenol after extraction with PVPP, the total concentration of tannins was obtained. Into tubes were added $0.5-\mathrm{mL}$ of the diluted extract, $3-\mathrm{mL}$ of butanol- $\mathrm{HCl}$ reagent and $0.1-\mathrm{mL}$ of ferric reagent, and later on, mixed. Tubes were heated at $100^{\circ} \mathrm{C}$ for 1-hour in a water bath. A blank of each sample (with and without dilution) was prepared without heating. After this step, tubes were cooled off and readings determined by UV-Vis spectrophotometry, with absorbance at $550 \mathrm{~nm}$, obtaining the results of condensed tannins, according to WATERMAN \& MOLE (1994).

\section{Performance evaluation}

The performance trial was carried out in swine production experimental area at Universidade Estadual Paulista, Botucatu, Brazil. A total of 72 piglets, females and castrated males of commercial lineage (Landrace x Large White) with an average initial weight of $7.11 \pm 0.76 \mathrm{~kg}$, weaned at an average age of 23 days were housed in a nursery facility with a ceiling height of $3.5 \mathrm{~m}$, side curtains and suspended metal pens of $1.75 \mathrm{~m}^{2}$ equipped with one feeder, one nipple-type drinker and one heater during initial phase. Pens had a partially slatted plastic flooring and a compact concrete floor under the heater. Internal temperature of nursery 
Table 1 - Chemical composition (values expressed on dry matter basis), geometric mean diameter values (GMD), pH and moisture levels of DCG, LTSG, HTSG, LTSS and HTSS; the organic acids profiles of LTSS and HTSS; total and condensed tannin percentages of LTSG, LTSS and HTSS used in performance trial.

\begin{tabular}{|c|c|c|c|c|c|}
\hline Analyses & $\mathrm{DCG}^{*}$ & LTSG $^{*}$ & $\mathrm{HTSG}^{*}$ & LTSS $^{*}$ & HTSS $^{*}$ \\
\hline $\mathrm{CP}(\%)$ & 9.53 & 12.18 & 9.66 & 12.06 & 9.00 \\
\hline CF $(\%)$ & 5.11 & 3.05 & 1.90 & 3.76 & 2.85 \\
\hline Minerals (\%) & 1.01 & 1.34 & 1.42 & 1.53 & 1.35 \\
\hline NFE $(\%)$ & 81.75 & 80.30 & 83.67 & 79.90 & 84.37 \\
\hline $\mathrm{CF}(\%)$ & 2.60 & 3.13 & 3.35 & 2.75 & 2.43 \\
\hline $\operatorname{GMD}(\mu \mathrm{m})$ & 653 & 525 & - & 1,062 & 1,116 \\
\hline $\mathrm{pH}$ & 5.77 & 6.20 & - & 3.80 & 4.00 \\
\hline Moisture (\%) & 11.03 & 12.08 & 12.12 & 29.33 & 29.50 \\
\hline Total organic acids ( $\% \mathrm{DM})$ & - & - & - & 0.94 & 1.20 \\
\hline Lactic (\%) & - & - & - & 59.92 & 76.40 \\
\hline Acetic (\%) & - & - & - & 15.44 & 8.30 \\
\hline Propionic (\%) & - & - & - & 23.74 & 13.09 \\
\hline Butyric (\%) & - & - & - & 0.90 & 2.21 \\
\hline Total tannins (\%) & - & 0.55 & 1.51 & 0.38 & 0.31 \\
\hline Condensed tannins (\%) & - & 0.48 & 1.17 & 0.01 & 0.08 \\
\hline
\end{tabular}

${ }^{*}$ DCG = dry corn grain; LTSG = dry sorghum with low-tannin; HTSG = dry sorghum with high-tannin; LTSS = high-moisture sorghum grain silage with low-tannin; HTSS = high-moisture sorghum grain silage high-tannin.

facility was controlled by adjustment of side curtains and management of heaters.

The experimental design was a randomized block assay with four treatments and six replicates. The criteria considered for blocks formation was weight, sex and litter. To each experimental unit (three animals) was randomly attributed the following treatments: diets based on dried corn grain (DCG); diets based on dry sorghum grain with low-tannin (LTSG); diets based on high-moisture sorghum grain silage with low-tannin (LTSS) and diets based on high-moisture sorghum grain silage with high-tannin (HTSS).

Throughout the experimental period (30 days), piglets were fed ad libitum within a phase feeding program to attend its nutritional requirements, in accordance with ROSTAGNO et al. (2005), except for crude protein and digestible energy, in the following phases: pre-starter diet I ( 0 to $8^{\text {th }}$ day), prestarter diet II (from $9^{\text {th }}$ up to $20^{\text {th }}$ day) and starter diet I (from $21^{\text {st }}$ to $30^{\text {th }}$ day) (Table 2). Dry matter (DM) contents of silages were adjusted for the same DM of correspondent dry sorghum grain using correction factors for replacement of dry sorghum grain by silages in diets. To determine the weight gain results, piglets were weighed at the beginning, at the $8^{\text {th }}$ and at $30^{\text {th }}$ experimental days. Feed intake was calculated at each phase, by the difference between the amount of feed provided and the amount of leftovers. The animals had free access to water and all data were submitted to analysis of variance by PROC GLM procedure of SAS (2001), and averages compared by Tukey's test $(\mathrm{P}<0.05)$.

\section{RESULTS AND DISCUSSION}

The geometric mean diameter (GMD) of particles of high-moisture sorghum grain silage was on average $100 \%$ higher than dry sorghum particles (Table 1). The GMD value of dry sorghum particles $(525 \mu \mathrm{m})$ was lower than dry corn particles $(653 \mu \mathrm{m})$, despite grinding of these cereals can be considered appropriate, results of experiments with pigs in the following phases: initial, growing, finishing and lactating have indicated that best particle size of dry corn and sorghum would be, respectively, $\leq 600 \mu \mathrm{m}$ and $\leq 500 \mu \mathrm{m}$ (HEALY et al., 1994; WONDRA et al., 1996).

The $\mathrm{pH}$ and organic acids concentrations are important qualitative indicators of ensiling process. The LTSS and HTSS pH values (Table 1) stood close to the range considered the most suitable for conservation of dry grains, which is about $3.8 \%$ to $5.0 \%$ (LOPES, 2004). The total organic acids content produced was $28 \%$ higher for HTSS compared to LTSS (Table 1). The LTSS and HTSS lactic acid 
Table 2 - Percentual composition and calculated nutritional values of experimental diets provided to piglets at each phase ${ }^{1}$.

\begin{tabular}{|c|c|c|c|c|c|c|c|c|c|}
\hline \multirow{2}{*}{$\begin{array}{l}\text { Ingredients } \\
\text { DCG }\end{array}$} & \multicolumn{3}{|c|}{------Phase I ( 0 to 8 days)------ } & \multicolumn{3}{|c|}{------Phase II (9 to 20days)------- } & \multicolumn{3}{|c|}{-----Phase III (21 to 30days)----- } \\
\hline & 40.00 & - & - & 55.95 & - & - & 64.39 & - & - \\
\hline LTSG & - & 41.500 & - & - & 57.95 & - & - & 64.93 & - \\
\hline HTSG & - & - & 38.80 & - & - & 54.45 & - & - & 60.93 \\
\hline Soybean meal & 20.00 & 18.50 & 21.20 & 23.00 & 21.00 & 24.50 & 27.54 & 27.00 & 31.00 \\
\hline Whey & 19.70 & 19.70 & 19.70 & 9.90 & 9.90 & 9.90 & - & - & - \\
\hline Blood cells $^{2}$ & 2.58 & 2.58 & 2.58 & 2.35 & 2.35 & 2.35 & - & - & - \\
\hline Wheat meal & 9.90 & 9.90 & 9.90 & 0,50 & 0.50 & 0.50 & - & - & - \\
\hline Sugar & 4.00 & 4.00 & 4.00 & 5.00 & 5.00 & 5.00 & 3.00 & 3.00 & 3.00 \\
\hline Soybean-oil & - & - & - & - & - & - & 1.50 & 1.50 & 1.50 \\
\hline Dic. phosphate & 1.67 & 1.67 & 1.67 & 1.58 & 1.58 & 1.58 & 1.74 & 1.74 & 1.74 \\
\hline Limestone & 0.74 & 0.74 & 0.74 & 0.75 & 0.75 & 0.75 & 0.82 & 0.82 & 0.82 \\
\hline Salt & 0.30 & 0.30 & 0.30 & 0.35 & 0.35 & 0.35 & 0.35 & 0.35 & 0.35 \\
\hline Premix $^{3}$ & 0.15 & 0.15 & 0.15 & 0.15 & 0.15 & 0.15 & 0.15 & 0.15 & 0.15 \\
\hline $\mathrm{CuSO}_{4}$ & - & - & - & 0.08 & 0.08 & 0.08 & - & - & - \\
\hline $\mathrm{ZnO} 77 \%$ & 0.29 & 0.29 & 0.29 & - & - & - & - & - & - \\
\hline Choline chloride & 0.04 & 0.04 & 0.04 & 0.03 & 0.03 & 0.03 & 0.03 & 0.03 & 0.03 \\
\hline L-Lys.HCl 78\% & 0.35 & 0.35 & 0.35 & 0.21 & 0.21 & 0.21 & 0.36 & 0.36 & 0.36 \\
\hline DL-Met 99\% & 0.10 & 0.10 & 0.10 & 0.06 & 0.06 & 0.06 & 0.04 & 0.04 & 0.04 \\
\hline L-Thr 99\% & 0.15 & 0.15 & 0.15 & 0.07 & 0.07 & 0.07 & 0.08 & 0.08 & 0.08 \\
\hline Antioxidant & 0.03 & 0.03 & 0.03 & 0.03 & 0.03 & 0.03 & - & - & - \\
\hline Total & \multicolumn{3}{|c|}{100.00} & \multicolumn{3}{|c|}{100.00} & \multicolumn{3}{|c|}{100.00} \\
\hline \multicolumn{10}{|c|}{ 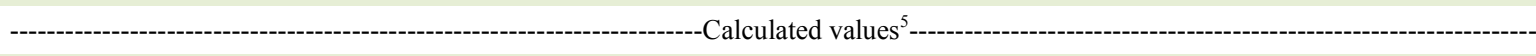 } \\
\hline $\mathrm{DE}\left(\mathrm{kcal} \mathrm{kg}^{-1}\right)$ & 3,366 & 3,330 & 3,219 & 3,381 & 3,317 & 3,174 & 3,439 & 3,367 & 3,207 \\
\hline Crude protein $(\%)$ & 19.25 & 19.92 & 19.73 & 19.37 & 20.19 & 19.97 & 18.92 & 20.45 & 20.23 \\
\hline $\mathrm{Ca}(\%)$ & 0.91 & 0.91 & 0.91 & 0.82 & 0.82 & 0.83 & 0.83 & 0.83 & 0.83 \\
\hline Total P (\%) & 0.66 & 0.66 & 0.67 & 0.62 & 0.63 & 0.64 & 0.62 & 0.63 & 0.64 \\
\hline Digestible Lys (\%) & 1.27 & 1.22 & 1.27 & 1.15 & 1.09 & 1.16 & 1.10 & 1.07 & 1.15 \\
\hline Digestible Met (\%) & 0.33 & 0.32 & 0.32 & 0.31 & 0.29 & 0.30 & 0.30 & 0.29 & 0.30 \\
\hline Digestible Thr (\%) & 0.78 & 0.76 & 0.78 & 0.72 & 0.68 & 0.68 & 0.67 & 0.66 & 0.70 \\
\hline Digestible Trp (\%) & 0.19 & 0.19 & 0.20 & 0.20 & 0.20 & 0.21 & 0.19 & 0.20 & 0.21 \\
\hline
\end{tabular}

DCG = dry corn grain; LTSG = dry sorghum with low-tannin; HTSG = dry sorghum with high-tannin ${ }^{1}$ The sorghum silage was replaced by correspondent amount of dry sorghum grain in diets based on same dry matter basis. ${ }^{2}$ AP-301 ${ }^{\circledR}$ (American Protein Corporation). ${ }^{3}$ Quantities supplied per kg of diet: $240 \mathrm{mg} \mathrm{Fe} ; 7.2 \mathrm{mg} \mathrm{Cu} ; 80 \mathrm{mg} \mathrm{Zn;} 48 \mathrm{mg} \mathrm{Mn}$; 0.48mg I; vit. A: 15,000I.U.; vit. D3: 1,500I.U.; vit. E: $50 \mathrm{mg}$; vit. $\mathrm{K}_{3}: 3 \mathrm{mg}$; vit. $\mathrm{B}_{1}: 2.50 \mathrm{mg}$; vit. $\mathrm{B}_{2}: 7 \mathrm{mg}$; vit. $\mathrm{B}_{3}: 35 \mathrm{mg}$; vit. $\mathrm{B}_{5}: 20 \mathrm{mg}$; vit. $\mathrm{B}_{6}: 4 \mathrm{mg}$; vit. $\mathrm{B}_{9}$ : $1.5 \mathrm{mg}$; vit. $\mathrm{M}$ : $150 \mathrm{~g}$; vit. $\mathrm{B}_{12} 35 \mathrm{ug}$; Se: 300ug. ${ }^{5}$ Calculated values based on chemical analysis and average composition of ingredients presented by ROSTAGNO et al. (2005).

concentrations were $0.56 \%$ and $0.92 \%$ on DM basis, respectively. Similar results were reported by HUCK et al. (1999), that used silage with original moisture grains or reconstituted grains using the same variety of sorghum at different moisture levels $(25 \%, 30 \%$ and $35 \%$ ) and, obtained $0.40 \%, 1.25 \%$ and $1.5 \%$ of lactate, respectively. The lactic acid values of silages were similar to those reported by PODKÓWKA
\& PODKÓWKA (2011), working with corn and sorghum silages. This acid is presented in higher quantities in relation to others, a desirable fact, once its presence favors the occurrence of homolactic fermentation, which prevents DM or energy losses (KUNG et al., 2003).

Moreover, synergistic action of lactic and acetic acids, when in suitable proportions in 
silage mass compared to other acids, improves the anaerobic stability phase of ensiling process, helping on control of spoilage bacteria, since $\mathrm{pH}$ lowering favors the faster change of bacteria profile, reducing proteolysis, protein deamination, promoting the best use of soluble carbohydrates and resulting in an increased retention of silage nutrients (PODKÓWKA \& PODKÓWKA, 2011).

Butyric acid levels reported in silages corroborated those found by FARIA JÚNIOR et al. (2011), which reported values between $0.2 \%$ to $2.5 \%$, values indicative of good fermentation and preservation of silage since population of Costridium spp., largest producer of acid in question, probably had its growth inhibited due to $\mathrm{pH}$ lowering, ensuring better quality of silage. Regarding acetic and propionic acids, these remained at intermediate levels between the lactic and butyric acids, values that agreed with FRANÇA et al. (2011) study, that used different sorghum hybrids as silage.

The ensiling process reduced total and condensed tannins concentrations, respectively about $31 \%$ and $98 \%$ for LTSS and, respectively, about $80 \%$ and $93 \%$ for HTSS (Table 1), which probably occurred due to acidity of medium and the action of microbial population in anaerobic silo environment, that contributed to deactivation of condensed tannins, which in acid medium, depolymerize to low molecular weight compounds. These results agreed with those that had demonstrated a decline on tannin content in HTSS at 20\% moisture level (PATRÍCIO et al., 2006). The maximum temperature reached inside silos during anaerobic fermentation process of LTSS $\left(28^{\circ} \mathrm{C}\right)$ and $\operatorname{HTSS}\left(25.83^{\circ} \mathrm{C}\right)$ were similar and, the difference on moisture content between silages was only about $0.17 \%$, which may explain the fact that percentage of condensed tannins reduction were close in both silages.

Concerning piglet's performance results, there were no effects of treatments on daily feed intake and daily weight gain at any of studied periods
(Table 3), corroborating the observed by PATRÍCIO et al. (2006). However, the feed: gain ratios of piglets fed LTSS was greater $(\mathrm{P}<0.05)$ compared to those fed dry sorghum at both studied phases. At total period, piglets that received HTSS showed similar feed:gain ratio to those that received dry corn or sorghum, but worse $(\mathrm{P}<0.05)$ than animals fed LTSS. Results of feed: gain ratio were probably due to reduction on tannin contents occurred during ensiling process, to the lower $\mathrm{pH}$ and to the structural changes in endosperm of ensiled grains.

An experiment conducted by MYER et al. (1986) with pigs from $28 \mathrm{~kg}$ to $98 \mathrm{~kg}$ reported an improvement of $3 \%$ on feed:gain ratio of pigs fed high-moisture sorghum grain silage at $25 \%$ moisture level compared to those that received dried grains. Best responses in performance, especially in feed: gain ratios were also verified by OLIVEIRA et al. (2004), TÓFOLI et al. (2006) and, TSE et al. (2006). The variations reported in the feed:gain ratio results may be related to differences on moisture levels of sorghum grains at ensiling time, providing greater or lower reduction on tannin contents and changes in structure of starch granules, as well as on quality of silage produced, that have been attributed to structural changes occurred in endosperm of ensiled sorghum and to the lower $\mathrm{pH}$ of diets containing silage.

The silage production process improves starch digestibility of sorghum grains (PATRÍCIO et al., 2006) depending on temperature levels and action of organic acids that occur during ensiling process, since temperature affects microbial growth, as well as enzymatic activity. The organic acids in turn promote breaking points on protein matrix that covers starch granules and in its structure, also acting on starch gelatinization (ROONEY \& PFLUGFELDER, 1986), favoring its digestion.

Furthermore, silage provides organic acids that may contribute to reduction of digesta buffering capacity (MROZ, 2005) and assist on piglet's

Table 3 - Average daily gain (ADG), daily feed intake (DFI) and feed:gain ratio (F:G) of piglets fed diets with dry corn (DCG), dry sorghum with low-tannin (LTSG), high-moisture sorghum grain silage with low-tannin (LTSS) or high-tannin (HTSS) during initial phase ${ }^{1}$.

\begin{tabular}{lccccccc}
\hline & Period (days) & DCG & LTSG & LTSS & HTSS & CV $(\%)^{3}$ & $P$-values \\
\hline \multirow{2}{*}{ ADG $(\mathrm{g})$} & 0 to 8 & 412 & 387 & 421 & 420 & 9.44 & 0.6409 \\
& 0 to 30 & 571 & 568 & 603 & 583 & 4.43 & 0.5501 \\
DFI $(\mathrm{g})^{2}$ & 0 to 8 & 575 & 581 & 532 & 567 & 6.44 & 0.5631 \\
& 0 to 30 & 1,044 & 1,100 & 1,036 & 1,100 & 5.79 & 0.5263 \\
F: $\mathrm{G}$ & 0 to 8 & $1.40^{\mathrm{ab}}$ & $1.52^{\mathrm{a}}$ & $1.27^{\mathrm{b}}$ & $1.36^{\mathrm{ab}}$ & 9.97 & 0.0352 \\
& 0 to 30 & $1.83^{\mathrm{ab}}$ & $1.93^{\mathrm{a}}$ & $1.72^{\mathrm{b}}$ & $1.88^{\mathrm{a}}$ & 4.39 \\
\hline
\end{tabular}

${ }^{1}$ Values followed by different lower case letters on lines differ by Tukey's test $(\mathrm{P}<0.05)$.

${ }^{2}$ Values of DFI set to same dry matter basis of dry sorghum.

${ }^{3} \mathrm{CV}=$ coefficient of variation. 
digestive process, reducing digestion incidence of post-weaning diarrhea syndromes and swelling syndrome in piglets at nursery phase (CHAMONE et al., 2010). In this context, it could be expected that the increase on digestibility of ensiled grains would improve efficiency of feed utilization, resulting in better feed:gain ratios.

\section{CONCLUSION}

Ensiling process decreases total tannin and condensed levels in sorghum. The high-moisture sorghum grain silages with low- and high-tannin in piglet's diets at nursery phase are an alternative for replacement of corn or dry sorghum with low-tannin without prejudice to piglets' performance. However, based on feed: gain ratio values, the high-moisture sorghum grain silage with low-tannin has better nutritional value compared to high-moisture sorghum grain silage with high-tannin for weanling pigs.

\section{ACKNOWLEDGEMENTS}

The authors acknowledge the financial support of this research (grant number: 02/00561-8) provided by Fundação de Amparo à Pesquisa do Estado de São Paulo (FAPESP) and Coordenação de Aperfeiçoamento de Pessoal de Nível Superior (CAPES) for the doctoral scholarship.

\section{BIOETHICS AND BIOSSECURITY COMMITTEE APPROVAL}

The research was performed with approval by The Animal Ethics Committee from this institution (protocol number 102/2015/CEUA) and, in accordance with the directive 86/609/EEC.

\section{REFERENCES}

AOAC (ASSOCIATION OF OFFICIAL ANALYTICAL CHEMISTS). Official methods of analysis of the Association of Official Analytical Chemists. 14.ed. Washington: AOAC International, 1984. $1121 \mathrm{p}$.

CHAMONE, J. M. A. et al. Digestive physiology of piglets. Revista Eletrônica Nutritime, v.7, n.5, p.1353-1363, 2010. Available from: $<$ http://www.nutritime.com.br/arquivos_internos/artigos/123V7N5 P1353 1363SET2010 .pdf $>$. Accessed: Jan. 27, 2016.

FARIA JÚNIOR, W. G. et al. Effect of grain maturity stage on the quality of sorghum BRS-610 silages. Arquivo Brasileiro de Medicina Veterinária e Zootecnia, v.63, p.1215-1223, 2011. Available from: <http://www.scielo.br/scielo.php?pi$\mathrm{d}=\mathrm{S} 0102-09352011000500024 \&$ script $=$ sci_arttext $>$. Accessed: 20 Nov. 2013. doi: 10.1590/S0102-09352011000500024.

FRANÇA, A. F. S. et al. Fermentative chracteristics of sorghum hybrids ensilage under nitrogen rates. Ciência Animal Brasileira, v.12, p.383-391, 2011. Available from: <http://www.revistas.ufg.br/index. php/vet/article/view/540>. Accessed: Ago. 01, 2013. doi: 10.5216/cab. v12i3.540.
HEALY, B. J. et al. Optimum particle size of corn and hard and soft sorghum for nursery pigs. Journal of Animal Science, v.72, n.9, p.2227-2236, 1994. Available from: <https://www. animalsciencepublications.org/publications/jas/articles/72/9/2227>. Accessed: Feb. 01, 2016.

HUCK, G. L. et al. Effect of reconstituting field-dried and earlyharvested sorghum grain on ensiling characteristics of the grain and on growth performance and carcass merit of feedlot heifers. Journal of Animal Science, v.77, p.1074-1081, 1999. Available from: $<$ https://www.animalsciencepublications.org/publications/jas/ abstracts/77/5/1066>. Accessed: Jan. 05, 2013.

KUNG, L. Jr. et al. Silage additives. In: BUXTON, D.R.; MUCK, R.E.; HARRISON, J.H. (Eds). Silage science and technology. Madison: American Society of Agronomy, 2003. p.305-360.

LEHNEN, C. R. et al. Lactating sows fed diets with high moisture corn silage and fumaric acid. Arquivo Brasileiro Medicina Veterinária e Zootecnia, v.63, n.1, p.214-221, 2011. Available from: <http://www. scielo.br/pdf/abmvz/v63n1/v63n1a31.pdf>. Accessed: Jan. 27, 2016. doi: 10.1590/S0102-09352011000100031.

LOPES, A. B. R. C. et al. High moisture grain corn silage for initial phase swine from 8 to $30 \mathrm{~kg}$. Boletim de Indústria Animal, v.58, n.2, p.181-190, 2001a. Available from: <revistas.bvs-vet.org.br/ bia/article/view/8892>. Accessed: Jan. 29, 2016.

LOPES, A. B. R. C. et al. High moisture corn silage for growing and finishing swine. Boletim de Indústria Animal, v.58, n.2, p.191-200, 2001b. Available from: <revistas.bvs-vet.org.br/bia/ article/download/8893/9484>. Accessed: Jan. 29, 2016.

LOPES, A. B. R. C. Efeito de métodos de preservação dos grãos úmidos de milho e de sorgo sobre a estrutura do endosperma, dos grânulos de amido e desempenho de leitões. 2004. 87f. Tese (Doutorado em Zootecnia) - Faculdade de Medicina Veterinária e Zootecnia, Universidade Estadual Paulista, Botucatu, SP.

MROZ, Z. Organic acids as potential alternatives to antibiotic growth promoters for pigs. Advances in Pork Production, v.16, p.169-182, 2005. Available from: <http://citeseerx.ist.psu.edu/ viewdoc/download?doi=10.1.1.457.1924\&rep=rep1\&type=pdf $>$. Accessed: Jan. 28, 2016.

MUCK, R. E.; DICKERSON, J. T. Storage temperature effects on proteolysis in alfalfa silage. Transactions of the ASAE, v.31, n.4, p.1005-1009, 1988. Available from: <http://elibrary.asabe. org/azdez.asp?AID=30813\&T=2>. Accessed: Mar. 09, 2016. doi: 10.13031/2013.30813.

MYER, R. O. et al. Nutritive value of high- and low-tannin grain sorghums harvested and stored in the high-moisture state for growing-finishing swine. Journal of Animal Science, v.62, p.1290-1297, 1986. Available from: <https://www. animalsciencepublications.org/publications/jas/abstracts/62/5/ JAN0620051290?search-result=1>. Accessed: Jul. 16, 2014.

OLIVEIRA, R. P. et al. Nutritive value and performance of piglets fed rations containing high moisture corn silage. Revista Brasileira de Zootecnia, v.33, p.146-156, 2004. Available from: $<$ http://www.scielo.br/pdf/rbz/v33n1/a19v33n1.pdf $>$. Accessed: Sep. 17, 2014. doi: 10.1590/S1516-35982004000100019.

PATRÍCIO, V. M. et al. Nutritional evaluation of high moisture sorghum silage grain of high or low tannin contents for nursery 
piglets. Revista Brasileira de Zootecnia, v.35, p.14061415, 2006. Available from: <http://www.scielo.br/pdf/rbz/ v35n4/21.pdf $>$. Accessed: Sep. 20, 2015. doi: 10.1590/S151635982006000500021 .

PODKÓWKA, Z.; PODKÓWKA, L. Chemical composition and quality of sweet sorghum and maize silages. Journal of Central European Agriculture, v.12, p.294-303, 2011 Available from: <https://jcea.agr.hr/articles/74892_Chemical_ composition_and_quality_of_sweet_sorghum_and_maize silages en.pdf $>$. Accessed: Ago. 23, 2014. doi: $\overline{10.5513 /}$ JCEA01/12.2.915.

ROONEY, L. W.; PFLUGFELDER, R. L. Factors affecting starch digestibility with special emphasis on sorghum and corn. Journal of Animal Science, v.63, n.5, p.1607-1623, 1986. Available from: $<$ https://www.animalsciencepublications.org/publications/jas/ tocs/63/5>. Accessed: Mar.10, 2016.

SCHOFIELD, P. et al. Analysis of condensed tannins: a review. Animal Feed Science and Technology, v.92, p.21-40, 2001. Available from: <http:/www.sciencedirect.com/science/article/ pii/S0377840101002280>. Accessed: jan. 28, 2016. doi: 10.1016/ S0377-8401(01)00228-0.

TÓFOLI, C.A. et al. Nutritional evaluation of high moisture corn silage with different oil contents for piglets in nursery phase. Arquivo Brasileiro de Medicina Veterinária e Zootecnia, v.58 p.1-15, 2006. Available from: <http://www.scielo.br/pdf/abmvz/ v58n6/33.pdf>. Accessed: oct. 12, 2014. doi: 10.1590/S010209352006000600033.

TSE, M. L. P. et al. Nutritional value of high moisture corn silage with differents particle sizes for piglets in nursery phase. Arquivo Brasileiro de Medicina Veterinária e Zootecnia, v.58, p.12141221, 2006. Available from: <http://www.scielo.br/pdf/abmvz/ v58n6/34.pdf>. Accessed: Oct. 17, 2014. doi: 10.1590/S010209352006000600034

TSILOYIANNIS, V. K. et al. The effect of organic acids on the control of porcine post-weaning diarrhoea. Research in Veterinary Science, v.70, p.287-293, 2001. Available from: <http://www.ncbi. nlm.nih.gov/pubmed/11676629>. Accessed: Jan. 28, 2016. doi: 10.1053/rvsc. 2001.0476 .

WATERMAN, P. G.; MOLE, S. Analysis of phenolic plant metabolites. Oxford: Wiley-Blackwell, 1994. 248p.

WONDRA, K. J. et al. Grinding, pelleting affects nutritional value of cereal grains, diets for swine. Feedstuffs, v.68, n.5, p.13-17, 1996. Available from: <http://trove.nla.gov.au/work/48914136?q\& versionId=61835018>. Accessed: Nov. 12, 2015.

ZANOTTO, L. D.; BELLAVER, C. Particle size determination method in swine and poultry ingredients of feed. Concórdia: EMBRAPA, Centro Nacional de Pesquisa Suínos e Aves, 1996. p.1-15. (Comunicado Técnico n.215). Available from: <http://www.cnpsa.embrapa.br/ sgc/sgc_publicacoes/cot215.pdf $>$. Accessed: Sep. 23, 2014. 